\title{
Concentration, Distribution and Comparison of Total and Bioavailable Heavy Metals in Top Soils of Bonab District in Zanjan Province
}

\author{
Abdolhossein H. Parizanganeh ${ }^{1 *}$, Vahid Bijnavand ${ }^{1}$, Abasali A. Zamani ${ }^{2}$, Ali Hajabolfath ${ }^{3}$ \\ ${ }^{1}$ Department of Environmental Sciences, Faculty of Science, Zanjan University, Zanjan, Iran; ${ }^{2}$ Department of Analytical Chemistry, \\ Faculty of Science, Zanjan University, Zanjan, Iran; ${ }^{3}$ Department of Geology, Faculty of Science, Zanjan University, Zanjan, Iran. \\ Email: zanganeh_h@yahoo.com
}

Received October $8^{\text {th }}, 2011$; revised November $10^{\text {th }}, 2011$; accepted December $28^{\text {th }}, 2011$

\begin{abstract}
Heavy metal contamination of soils is a widespread problem in Zanjan province located in North West Iran due to natural pedo geochemical background and anthropogenic sources. The province is highly polluted by some heavy metals due to the presence of mineral resources notably Lead and Zinc, their improper utilization, and also the development of a number of related industries. Bonab district was selected for detail study and the objectives of the study were set to evaluate the total as well as bioavailable fraction of heavy metals in surficial soils within the studied area. 72 soil samples were collected and analyzed for heavy metal contamination by Atomic Absorption Spectrometry (AAS). The obtained results when compared with WHO and USEPA standards show a very high concentration of some toxic metals. Soils were basically polluted by $\mathrm{Pb}, \mathrm{Zn}, \mathrm{Cu}$, and $\mathrm{Cd}$. Bioavailable fraction of studied metals were also measured with formation of metal complex with Diethylene tri amine penta acetic acid (DTPA) agent. To find the share of the anthropogenic sources in the contamination of soils, the Enrichment factor (EF) and Geological Accumulation Index were measured and the distribution maps were drawn using Arc GIS (9.3). Highest concentrations of some toxic metals were found as isolated patches around the Bonab Industrial Town as well as within and around the most populated areas of the district notably Zanjan city indicating its anthropogenic origin.
\end{abstract}

Keywords: Soil Pollution; Pedogeochemical; Anthropogenic; Heavy Metals; Zanjan-Iran

\section{Introduction}

Heavy metal contamination of soils is widespread and there is a risk of transfer of toxic and available metals to human, animals, and agricultural crops [1]. Heavy metals are natural constituents of the Earth crust. A number of these elements are biologically essential at trace levels and play an important role in human health [2]. The potential risk for the environment and population due to soil heavy metals arising from metallic mining has been well described [3]. Heavy metals can induce toxicity in wildlife if the soil level reaches critical values; also plant accumulation in above-ground tissues can result in an increase of metal accumulation in top-soil, via leaf deposition, or can create an exposure pathway for metal introduction into the food chain [4]. In contrast with soils in agricultural areas, soils in urban environment, particularly in parks and gardens, have a direct influence on public health not related with production of food. This is due to that they come easily in contact with humans and

${ }^{*}$ Corresponding author. are transferred to them, either as suspended dust or by direct contact [5]. Two main sources of heavy metals in soils can be considered: 1) the natural pedo-geochemical background, which represents the heavy metal concentration inherited from the parent rock [6] and 2) anthropogenic contamination, which can be directed via wastes, animal manure [7], compost [8], sewage sludge [9], or diffuse via aerosol deposition [10]

Angoran area of Zanjan province located in North West of Iran has a large metalliferous site and has been considered as a traditional mining region since antiquity. There are still large reserves of lead $(\mathrm{Pb})$ and zinc $(\mathrm{Zn})$ in the area. Both mines and smelting units in the province present a risk of contamination of soils, plants, surface and ground water by dissemination of the particles carrying metals by wind action and/or by runoff from the tailings. Heavy metal contamination in Zanjan province has also been previously reported in the vicinity of Lead and Zinc mining and smelting sites [11,12]. The total heavy metal contents can indicate the extent of contamination, but is not usually an accurate indication of the 
phyto-toxicity; so many latest studies investigated the heavy metal fractions of mine soils [13] and evaluated the phyto-toxic risk for human receptors. However, the determination of heavy metal fractions is a more complex task than the determination of the total contents of heavy metals [14]. The main purpose of this research is the measurement of the quantity of heavy metals existing in top soils of the study area, the determination of the rate of the bioavailable elements in top soil is also one of the pillars of this research, since this part aside from polluted or unpolluted the soils, show the absorption ability of the plants.

\section{Materials and Methods}

\subsection{The Study Site}

In this study the Bonab district located near the city of Zanjan was selected for detailed study. Soil samples were collected from the studied area during second week of October 2010 (Figure 1).

\subsection{Sample Collection}

Seventy two soil samples were collected through systematic random sampling (top $0-30 \mathrm{~cm}$ soil layer). The study area was divided into a $4 * 4 \mathrm{~km}$ grid and samples were collected from every corner of the grid. Based on the information gathered through field trips and taking into account the type of landuse and population concentration, the numbers of samples were increased by subdividing the grid in selected locations ( $2.2 \mathrm{~km}$ grid).

Soil samples were collect from the surface of the soil ( 0 - $30 \mathrm{~cm}$ deep) and preserved by using the methods of soil analysis [15]. From each sampling points, four soil samples were gathered and mixed properly to obtain a composite sample mixture. The soil sampling spots were cleared of debris before sampling. Each composite soil samples were placed in cellophane bags labeled then taken to the laboratory for pre-treatment and analysis. The sampling tools, were washed with soap and rinsed with distilled water after each sampling [16].

\subsection{Soil Analysis}

In the laboratory, bulk soil samples were spread on trays and were air dried at ambient conditions for two weeks. The samples were then grounded by mortar and pestle, sieved through a $2 \mathrm{~mm}$ mesh, and oven-dried at $50^{\circ} \mathrm{C}$ for about 48 hours. The samples were then stored in polyethylene bags and re-homogenized before being used. The soil samples were digested using the 11466 ISO standard methods (the aqua regia digestion method) [17]. $3 \mathrm{~g}$ of soil was placed in a $100 \mathrm{ml}$ round bottom flask with $21 \mathrm{ml}$ of concentrated $\mathrm{HCl}(35 \%)$ and $7 \mathrm{ml}$ concentrated $\mathrm{HNO}_{3}(65 \%)$. The solution was kept at room temperature overnight before a water condenser was attached and the solution heated to boiling point for 2 hours. Added $25 \mathrm{ml}$ water to the condenser before filtration of the mixture through using a Whatman (No. 42) filter. The filtered residue was rinsed twice with $5 \mathrm{ml}$ of water and the solution was made up to $100 \mathrm{ml}$. The bioavailable content of metals were determined using Lindsey method (Lindsay, 1978), $10 \mathrm{~g}$ of soil was added in $20 \mathrm{~mL}$ mixture of $0.005 \mathrm{~mol} \cdot \mathrm{L}^{-1} \mathrm{DTPA}$ and $0.01 \mathrm{~mol} \cdot \mathrm{L}^{-1} \mathrm{CaCl}_{2}$ and $0.01 \mathrm{~mol} \cdot \mathrm{L}^{-1}$ triethylamine $(\mathrm{pH} 7.3)$, shaken for $2 \mathrm{~h}$ and then filtered through using a Whatman (No. 42) filter.

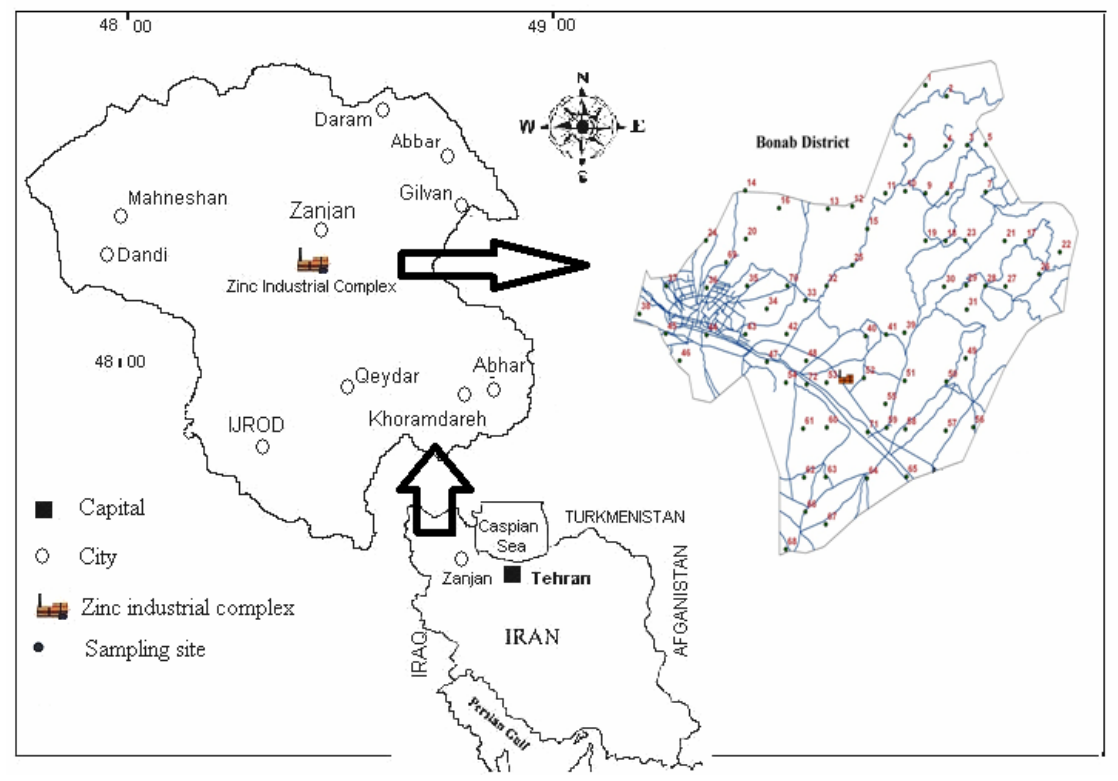

Figure 1. Location map of the studied area indicating sampling points. 
The metals ( $\mathrm{Zn}, \mathrm{Pb}, \mathrm{Cu}, \mathrm{Fe}, \mathrm{Ni}, \mathrm{Co}$ and $\mathrm{Cd}$,) in the soil extracts were analyzed by Atomic Absorption Spectrometry (AAS). Three analytical replicates were measured for each sample. Data with replicates were presented as mean-standard error and difference test was made using SPSS 14 software. The $\mathrm{pH}$ and EC (solid: distilled water $=1: 5$ ) of the soil samples were also measured by with $\mathrm{pH}$ and EC meters (Metrohm, Germany). Finally, using the geostatistical methods with Arc GIS (9.3) the heavy metal distribution maps were drawn.

\section{Results and Discussion}

\section{Total Heavy Metal in Soils}

Comparing the results with standard range, shows that the concentrations of heavy metals $\mathrm{Pb}, \mathrm{Zn}, \mathrm{Cu}, \mathrm{Cd}$ in the studied area are higher than standards. Summary statistics for the analyzed elements in all the studied samples are presented in Table 1. Though, Cadmium has the lowest mean concentration $(1.49 \mathrm{mg} / \mathrm{kg})$, it is well above the maximum permissible limits given by all existing standards (Table 2). While the highest contents are for $\mathrm{Fe}$ $(66933.7 \mathrm{mg} / \mathrm{kg}), \mathrm{Pb}, \mathrm{Zn}$, and $\mathrm{Cd}$ are also much higher than standards and do not relate to the pedo geochemical sources. These points out that Zinc industry are most possibly the major anthropogenic source for the enrichment of these heavy metals in the top soil. The extremely high metal levels in tailings made them a potentially hazardous source of soil contamination. Soil $\mathrm{pH}$ averaged 7.78 (from 7.16 to 8.08 ) indicating a neutral to alkaline nature. Electrical conductivity (EC) in the samples is quite variable ranging from 248 to $1721 \mu \mathrm{s} \cdot \mathrm{cm}^{-1}$.

The concentration of the studied metals are in the order of $\mathrm{Fe}>\mathrm{Zn}>\mathrm{Cu}>\mathrm{Pb}>\mathrm{Ni}>\mathrm{Co}>\mathrm{Cd}$.

The bioavailable heavy metals [19] content in soil samples are less than total metal content. With increasing total heavy metal content in soils, the bioavalaible content of metals are also increase and there are a significant correlation between them, (Table 3).

Figure 2 shows the concentration and distribution of each metal within the studied area. Zinc concentration (Figure 2(a)) is very high in Bonab industrial town and its damping site located in the center of the studied area, indicating its anthropogenic source. Lead is also found in some localized areas with extremely high concentrations among them the Bonab industrial town and its damping area and can be related to Zanjan Zinc and Lead smelting plant. Lead is also found in high concentration in Zanjan city area which is mainly due to traffic and use of leaded gasoline and also may by air borne (Figure 2(b))

Table1. The nature of the soil samples and total metal concentrations in the top soil $\left(\mathbf{m g} \cdot \mathbf{k g}^{-1}\right)$.

\begin{tabular}{ccccccccc}
\hline $\mathrm{pH}$ & $\mathrm{EC}\left(\mu \mathrm{s} \cdot \mathrm{cm}^{-1}\right)$ & $\mathrm{Pb}$ & $\mathrm{Zn}$ & $\mathrm{Cd}$ & $\mathrm{Cu}$ & $\mathrm{Co}$ & $\mathrm{Ni}$ & $\mathrm{Fe}$ \\
\hline Avg. 7.80 & 491.1 & 58.18 & 299.31 & 1.4 & 67.68 & 18.53 & 28.11 & 66933.7 \\
Max. 8.08 & 1721.0 & 615.3 & 13461.67 & 5.6 & 3106.6 & 41.97 & 69.20 & 157916.7 \\
Min. 7.16 & 248.0 & 14.33 & 25.10 & 0.3 & 0.83 & 8.53 & 1.07 & 30950.0 \\
Median 7.80 & 425.0 & 38.16 & 93.96 & 1.3 & 20.65 & 18.87 & 25.85 & 61583.3 \\
STDEV 0.17 & 251.9 & 91.42 & 1574.91 & 0.7 & 346.51 & 4.92 & 14.35 & 23102.9 \\
\hline
\end{tabular}

Table 2. Metal concentrations were compared with existing standard $\left(\mathrm{mg}^{\circ} \mathbf{k g}^{-\mathbf{1}}\right)$ [18].

\begin{tabular}{cccccccc}
\hline Standard & $\mathrm{Pb}$ & $\mathrm{Zn}$ & $\mathrm{Cd}$ & $\mathrm{Cu}$ & $\mathrm{Co}$ & $\mathrm{Ni}$ & $\mathrm{Fe}$ \\
\hline USEPA $^{1}$ & 10 & $\mathrm{NR}$ & - & 30 & 8 & 40 & $\mathrm{NR}$ \\
GLC $^{2}$ & 20 & $\mathrm{NR}$ & - & $\mathrm{NR}$ & $\mathrm{NR}$ & 20 & $\mathrm{NR}$ \\
WHO & 20 & 50 & 0.3 & 4 & 19 & 68 & 47200 \\
Average in the study area & 58.18 & 299.31 & 1.4 & 67.68 & 18.53 & 28.11 & 66933.70 \\
\hline
\end{tabular}

${ }^{1}$ United State Environmental Protection Agency; ${ }^{2}$ Great London Council.

Table 3. Bioavailable heavy metal content in the top soil $\left(\mathrm{mg} \cdot \mathrm{kg}^{-\mathbf{1}}\right)$.

\begin{tabular}{cccccccc}
\hline & $\mathrm{Pb}$ & $\mathrm{Zn}$ & $\mathrm{Cd}$ & $\mathrm{Cu}$ & $\mathrm{Co}$ & $\mathrm{Ni}$ & $\mathrm{Fe}$ \\
\hline Avg. & 4.68 & 2.00 & 0.15 & 1.92 & 0.32 & 0.59 & 6.88 \\
Max. & 71.00 & 10.50 & 1.04 & 13.30 & 1.01 & 2.57 & 38.2 \\
Min & 0.06 & 0.07 & 0.05 & 0.14 & 0.09 & 0.08 & 1.68 \\
Median & 2.80 & 1.21 & 0.10 & 1.48 & 0.26 & 0.49 & 5.47 \\
STDEV & 8.77 & 2.23 & 0.16 & 1.48 & 0.20 & 0.42 & 5.39 \\
\hline
\end{tabular}



Bonab District in Zanjan Province

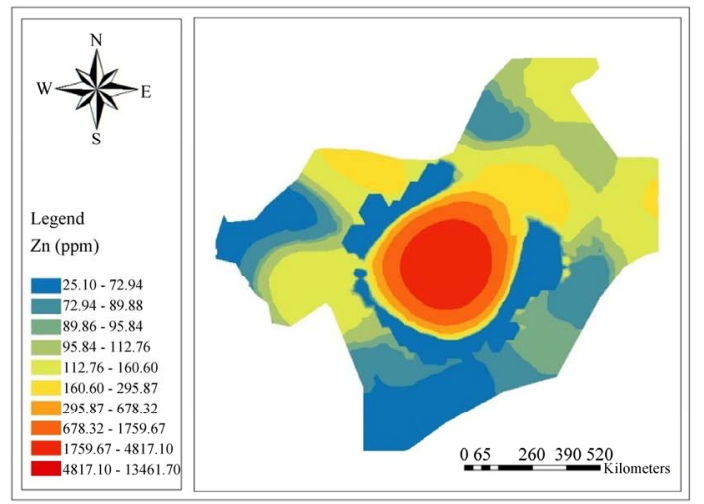

(a)

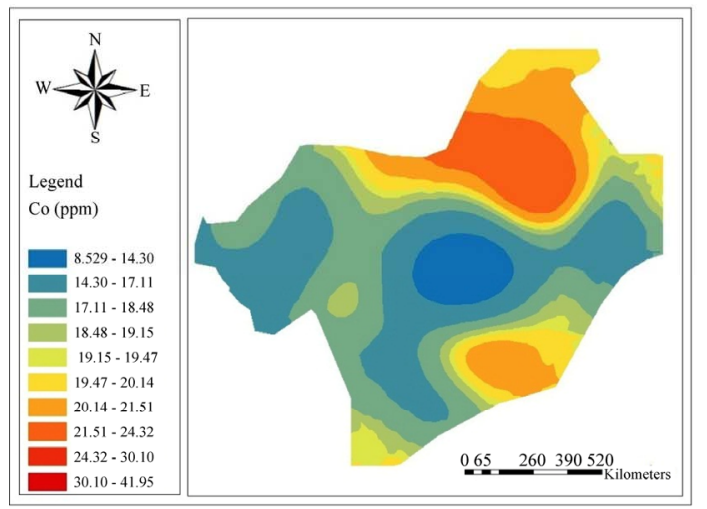

(c)

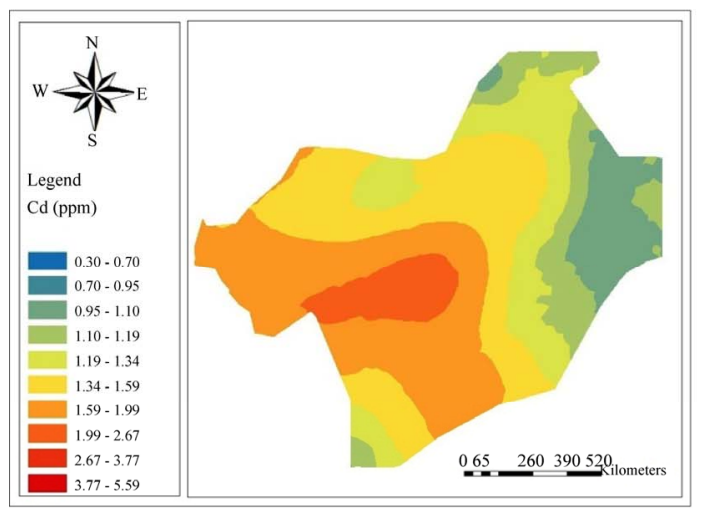

(e)

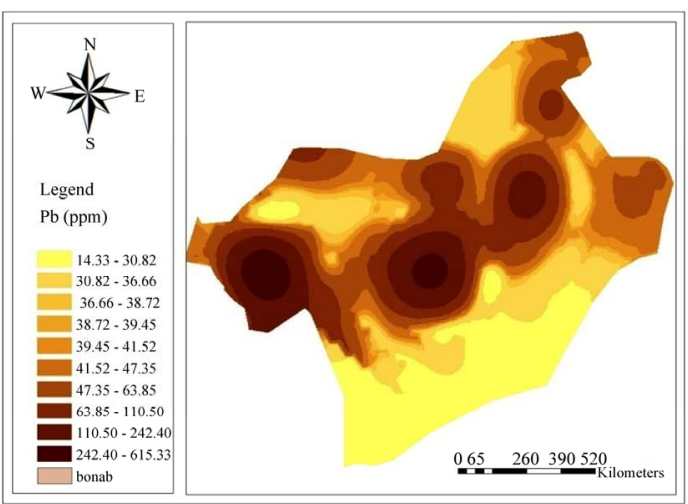

(b)

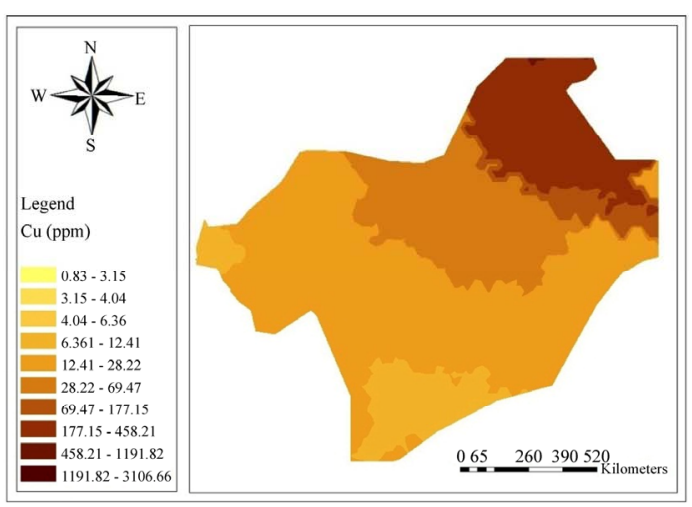

(d)

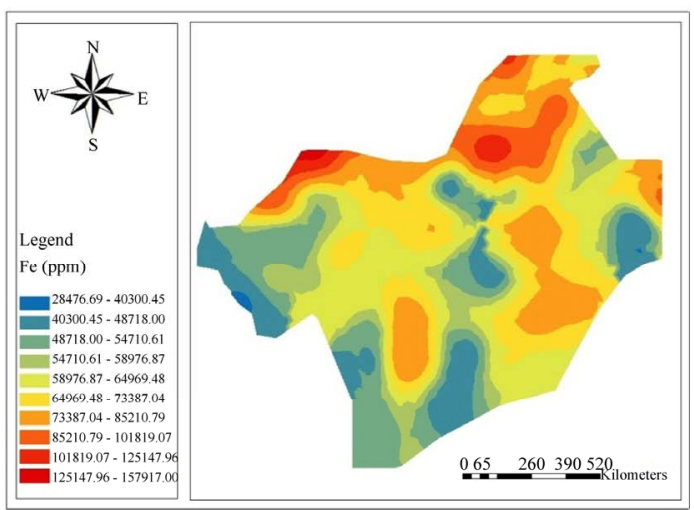

(f)

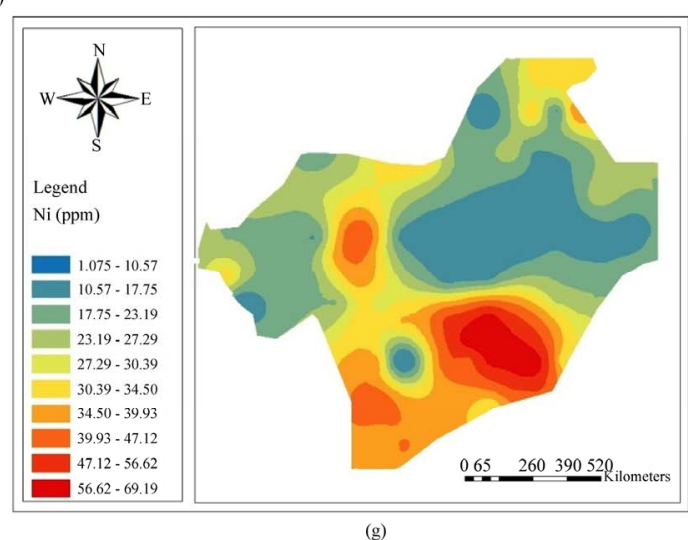

Figure 2. Concentration \& distribution of (a) Zn; (b) Pb; (c) Co; (d) Cu; (e) Cd; (f) Fe; (g) Ni. 
Significant correlation between concentration of $\mathrm{Cu}$, $\mathrm{Co}$, and $\mathrm{Fe}$ in the north east of the studied area (Figures 2(c), (d) and (f)) are mainly natural pedo-geochemical background and maybe related to the Zaker (Fe) mining area .

Nickel is also found in high concentration in south east of the area its high concentration may be related to agricultural fertilizer used in the cultivated lands in this part of the studied area (Figure 2(g)).

\section{Enrichment Factor (EF)}

A common approach to estimate how much the sediment is impacted (naturally and anthropogenically) with heavy metal is to calculate the Enrichment Factor (EF) for metal concentrations above un-contaminated background levels [20]. Pollution will be measured as the amount or ratio of the sample metal enrichment above the concentration present in the reference station or material $[21,22]$. The EF method normalizes the measured heavy metal content with respect to a samples reference such as Fe, $\mathrm{Al}$ or $\mathrm{Zn}$ [21]. The EF of a heavy metal in sediment can be calculated with the following formula [20]:

$$
\mathrm{EF}=\frac{\mathrm{C}_{\text {metal }} / \mathrm{C}_{\text {normalizer }}}{\mathrm{C}_{\text {metal control }} / \mathrm{C}_{\text {normalizer control }}}
$$

where $\mathrm{C}_{\text {metal }}$ and $\mathrm{C}_{\text {normalizer }}$ are the concentrations of heavy metal and normalizer in sediment and in unpolluted soil. Enrichment factor (EF) can be used to differentiate between the metals originating from anthropogenic activities and those from natural procedure, and to assess the degree of anthropogenic influence. Five contamination categories are recognized on the basis of the enrichment factor as follows: [23].

$\mathrm{EF}<2$ is deficiency to minimal enrichment,

EF 2 - 5 is moderate enrichment,

EF 5 - 20 is significant enrichment,

EF 20 - 40 is very high enrichment,

$\mathrm{EF}>40$ is extremely high enrichment.

As the EF values increase, the contributions of the anthropogenic origins also show an increase [22]. Figure 3 shows the EF for heavy metals $\mathrm{Cd}(\mathrm{a}), \mathrm{Pb}(\mathrm{b}), \mathrm{Cu}$ (c), Co (d), $\mathrm{Zn}(\mathrm{e})$, and $\mathrm{Ni}$ (f) in the study area.

\section{Index of Geo-accumulation}

Index of Geo-accumulation (Igeo) has been used widely to evaluate the degree of metal contamination or pollution in terrestrial, aquatic and marine environment. The Igeo of a metal in sediment can be calculated with the fallowing formula [21]:

$$
\text { Igeo }=\log 2 \mathrm{C}_{\text {metal }} / 1.5 \mathrm{C}_{\text {metal }}(\text { Control })
$$

where $\mathrm{C}_{\text {metal }}$ is the concentration of the heavy metal in the enriched sample and $\mathrm{C}_{\text {metal(control) }}$ is the concentration of the metal in the unpolluted or control sample. The factor 1.5 is introduced to minimize the effect of the possible variations in the background or control values which may be attributed to lithogenic variations in the sediment [21]. The degree of metal pollution is assessed in terms of seven contamination classes based on the increasing numerical value of the index as follows: [20].

Igeo $<0=$ means unpolluted

$0 \leq$ Igeo $<1$ means unpolluted to moderately polluted,

$1 \leq$ Igeo $<2$ means moderately polluted,

$2 \leq$ Igeo $<3$ means moderately to strongly polluted,

$3 \leq$ Igeo $<4$ means strongly polluted,

$4 \leq$ Igeo $<5$ means strongly to very strongly polluted,

Igeo $\geq 5$ means very strongly polluted.

Figure 4 shows the Index of Geo-accumulation for heavy metals $\mathrm{Pb}$ (a), $\mathrm{Co}$ (b), $\mathrm{Cu}$ (c), Fe (d), Zn (e), Cd (f) and $\mathrm{Ni}(\mathrm{g})$ in the studied area.

\section{Conclusions}

72 soil samples were analyzed to determine the concentration and distribution of heavy metals $(\mathrm{Cd}, \mathrm{Pb}, \mathrm{Ni}, \mathrm{Cu}$, $\mathrm{Co}, \mathrm{Fe}$ and $\mathrm{Zn}$ ) in top soils of Bonab district in ZanjanIran. Determination of bioavailability of heavy metal in soils with DTPA method has been shown that by increasing total amount of heavy metals in soil, the bioavailable content of heavy metal also will show an increased. The dispersion maps provided for lead shows that the most concentration of lead is near the industries specially near Iran Lead and Zinc Factory and also observed in the Zanjan City so it is possible to conclude that the concentration of lead in the soils of study area is related to industries on the other hand the pollution is because of human activities.

According to the dispersion maps provided for nickel and landuse map of study area it was observed that the concentration of nickel has a direct relationship with landuse in study area as such as the most concentration of nickel existed in the agricultural lands confirm of the study area which it is due to the over use of chemical fertilizer in this area.

For $\mathrm{Cd}$ and $\mathrm{Zn}$ the maximum concentration observed near the Iran Lead and Zinc Factory and industrial areas but for the $\mathrm{Fe}, \mathrm{Cu}$, and $\mathrm{Co}$ heavy metals obviously observed that the concentration of this metals in top soils is just related to the structural geology and the rock kinds of the study area as it was observed that the average of $\mathrm{Fe}, \mathrm{Pb}, \mathrm{Zn}, \mathrm{Cu}$, and $\mathrm{Cd}$ in sequence in top soils are $66933.70,58.18,299.31,67.68,1.49 \mathrm{mg} \cdot \mathrm{kg}^{-1}$ and the average of this metals according to the WHO standard in sequence are $47,200,20,50,45,0.3 \mathrm{mg} \cdot \mathrm{kg}^{-1}$. This means that the study area is polluted by these heavy metals. For $\mathrm{Co}$ and $\mathrm{Ni}$, the average concentrations in sequence are 


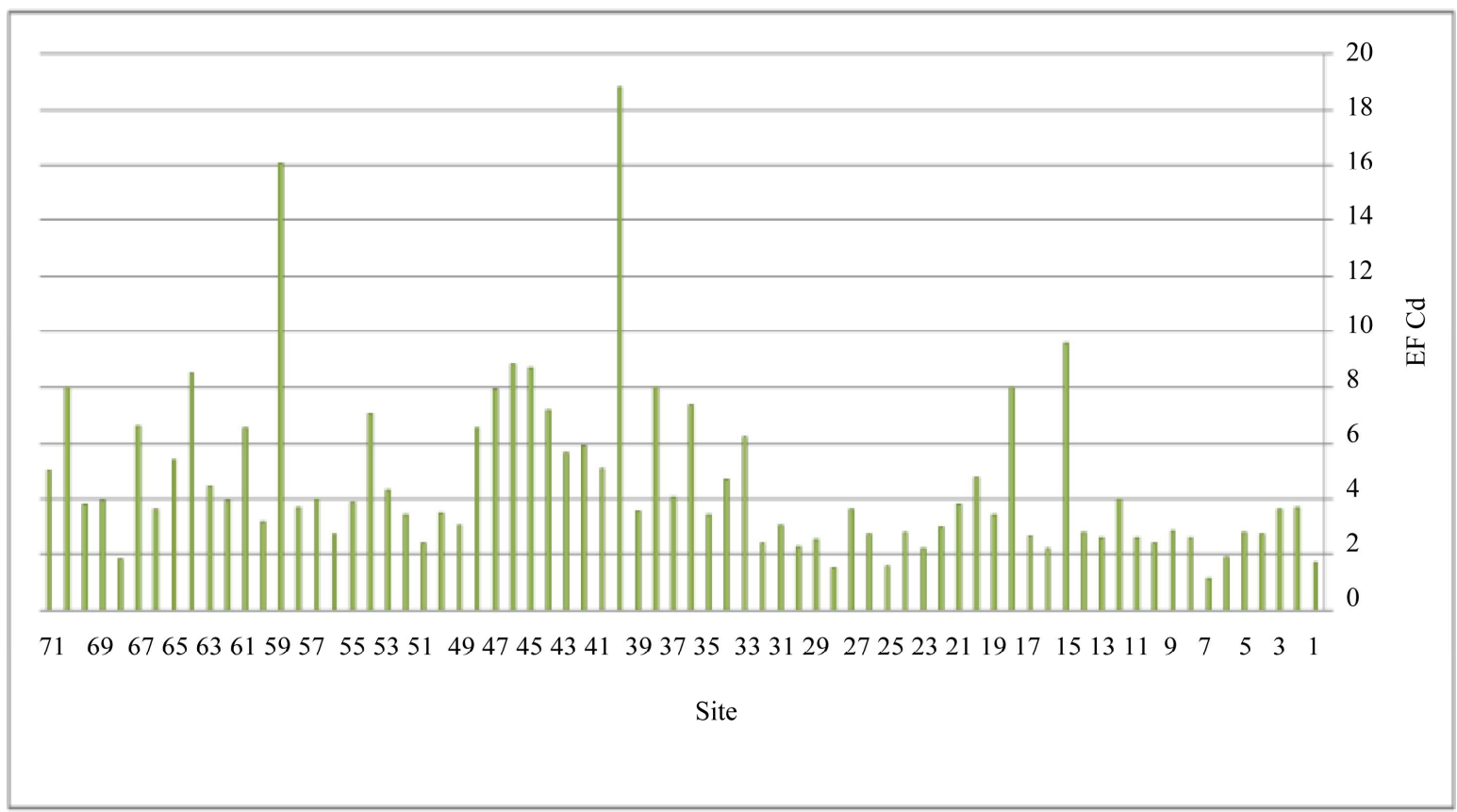

(a)

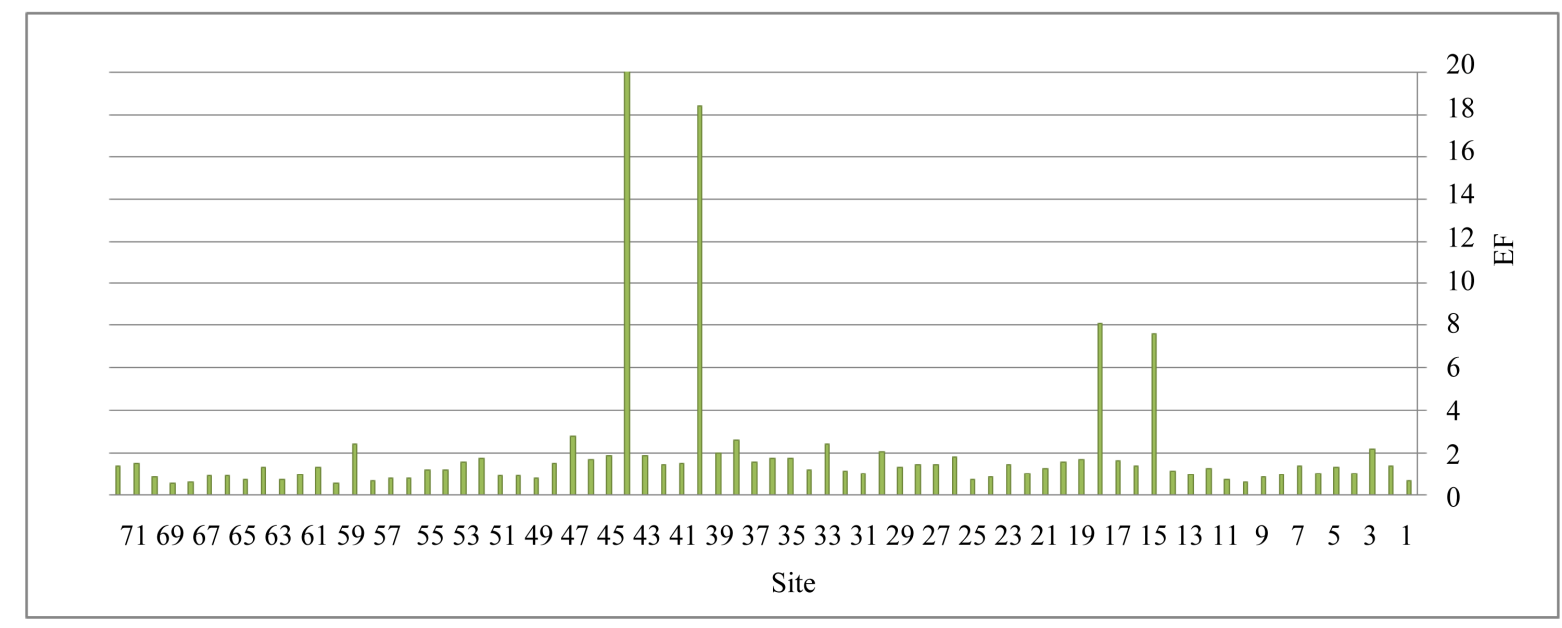

(b)

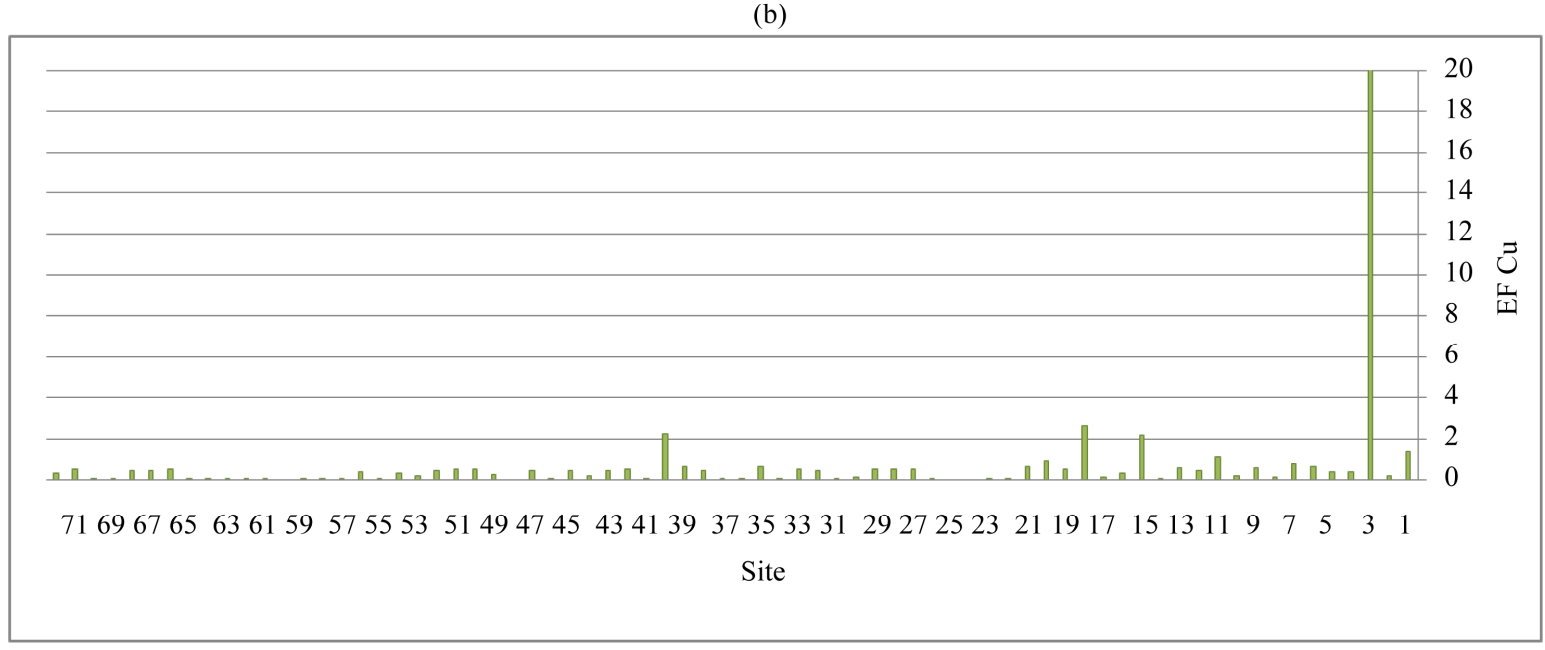

(c) 


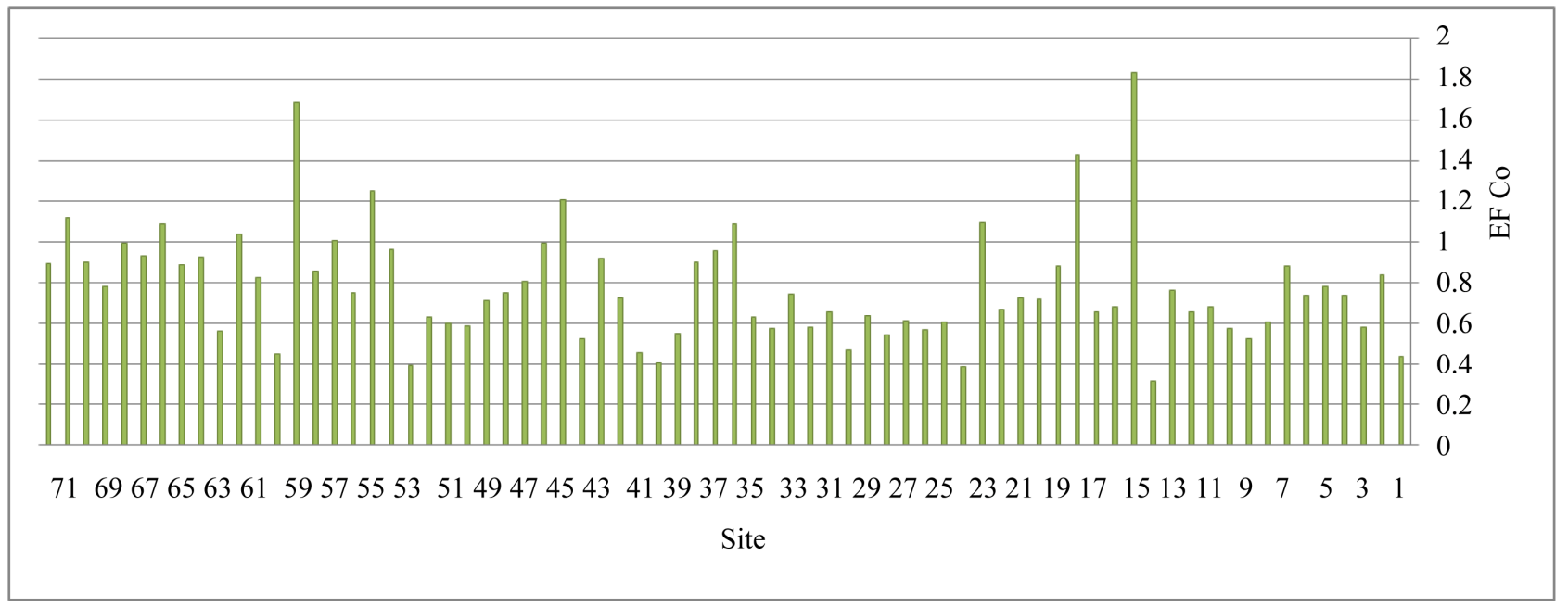

(d)

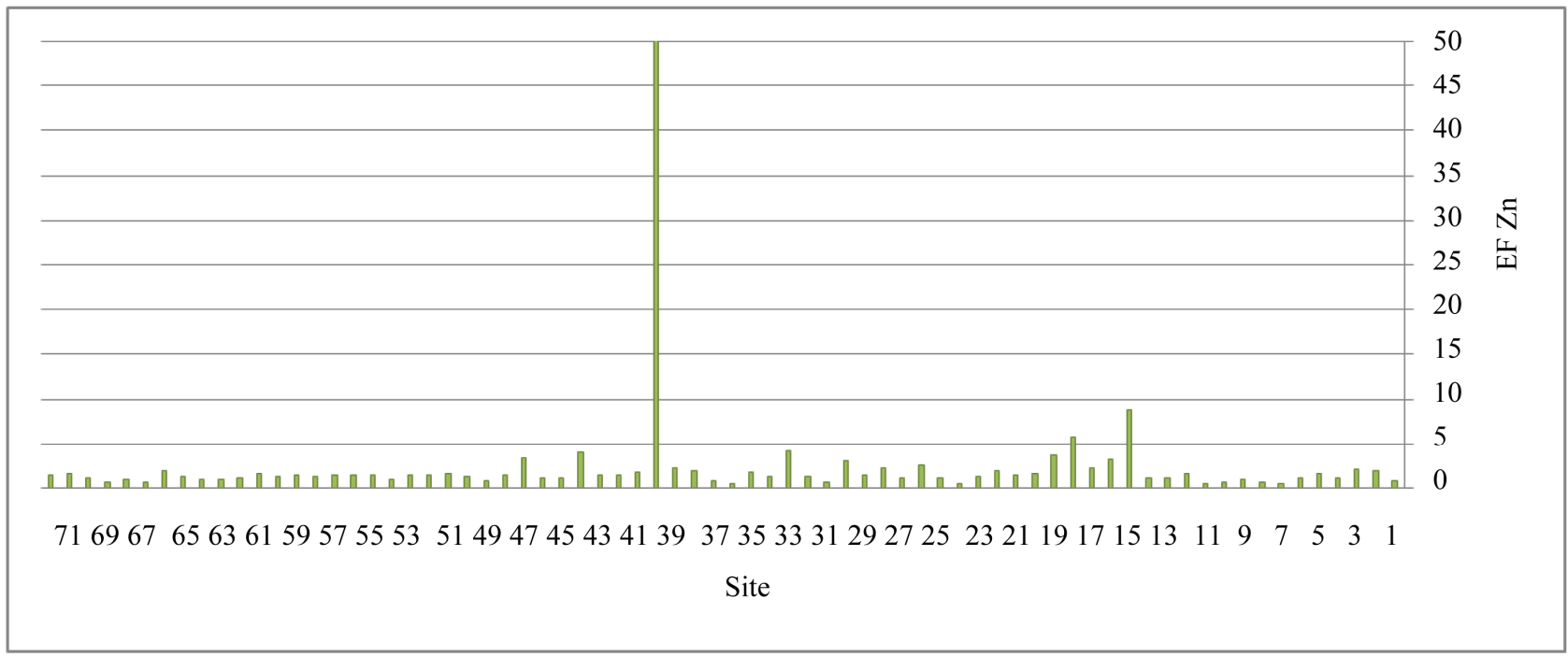

(e)

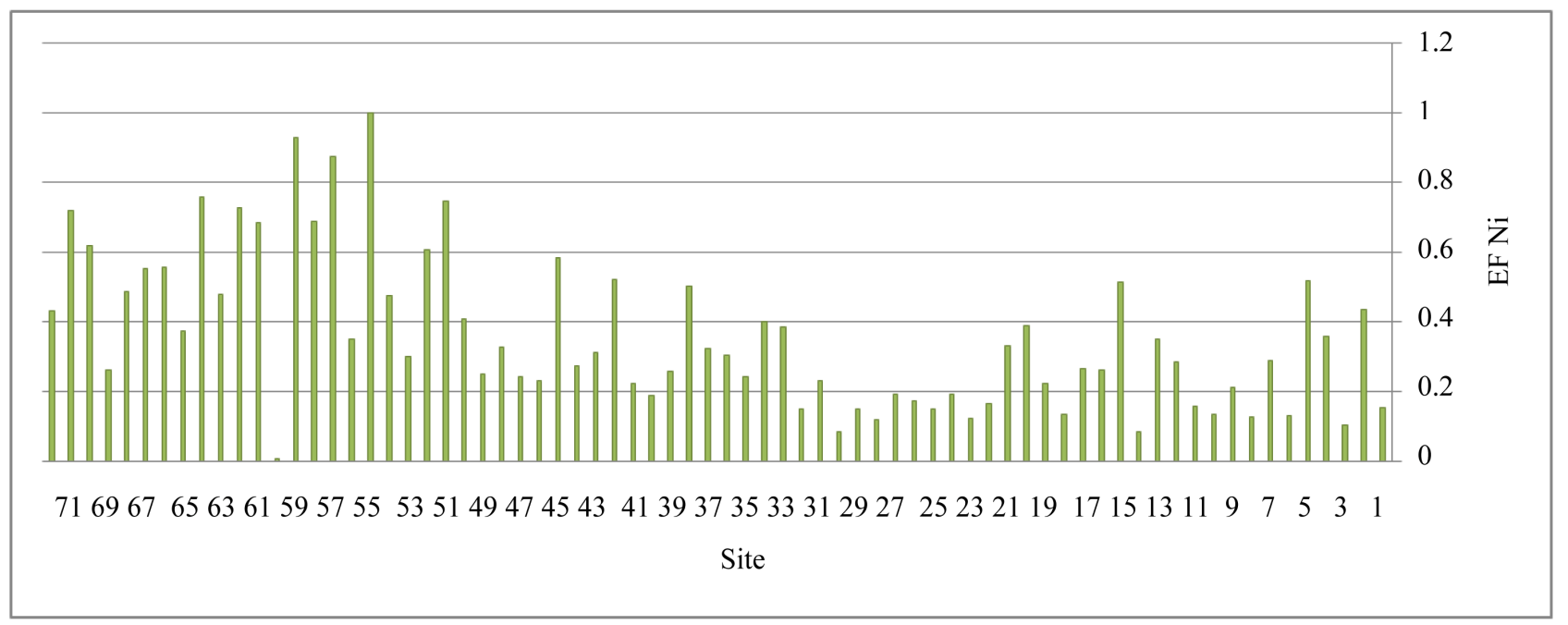

(f)

Figure 3. Enrichment Factor (EF) for heavy metals Cd (a), Pb (b), Cu (c), Co (d), Zn (e), and Ni (f) in the study area. 


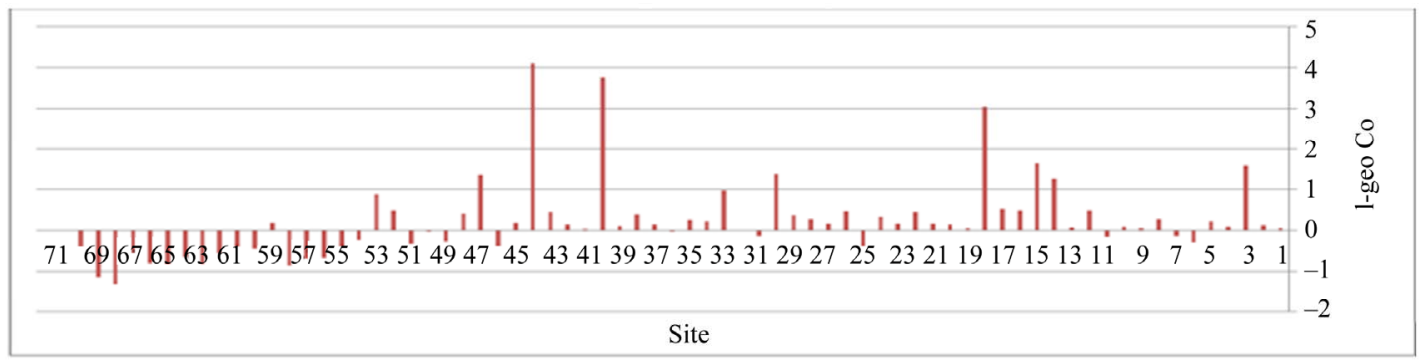

(a)

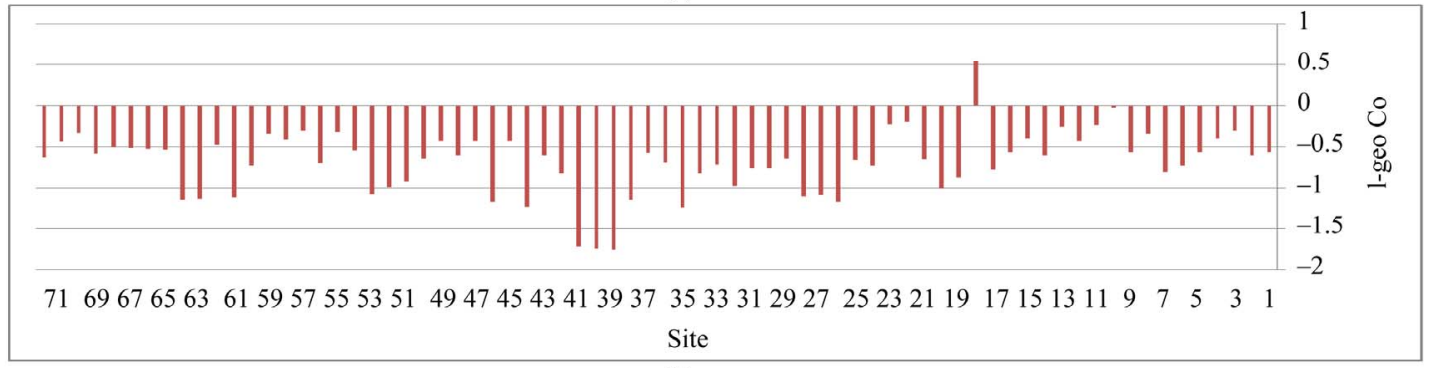

(b)

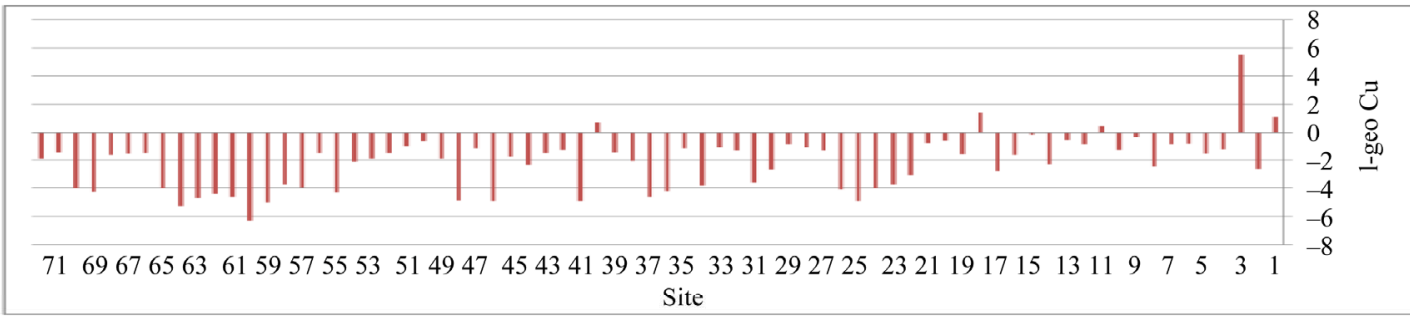

(c)

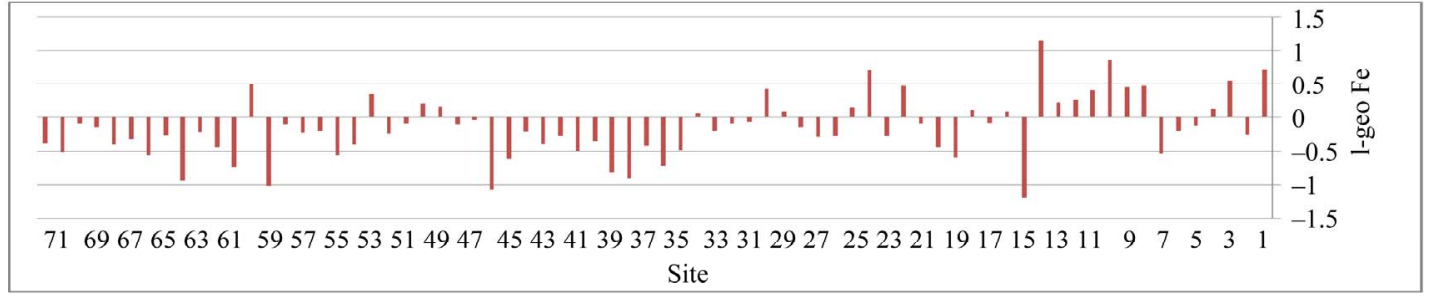

(d)

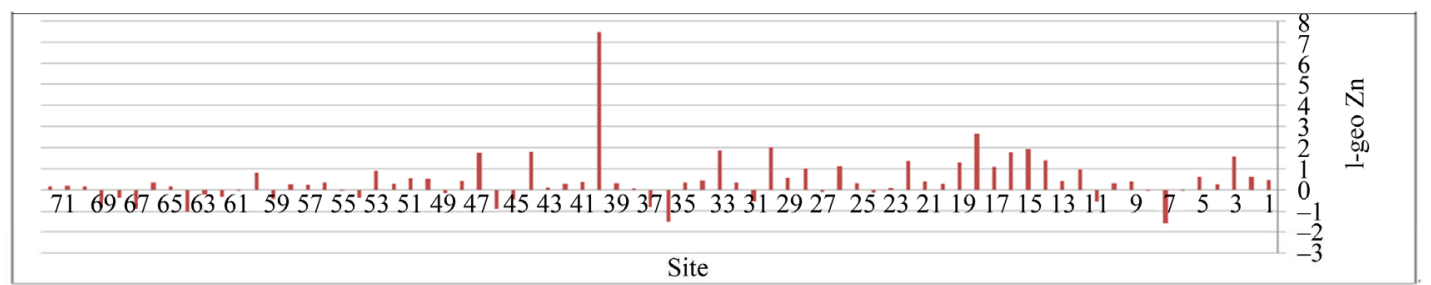

(e)

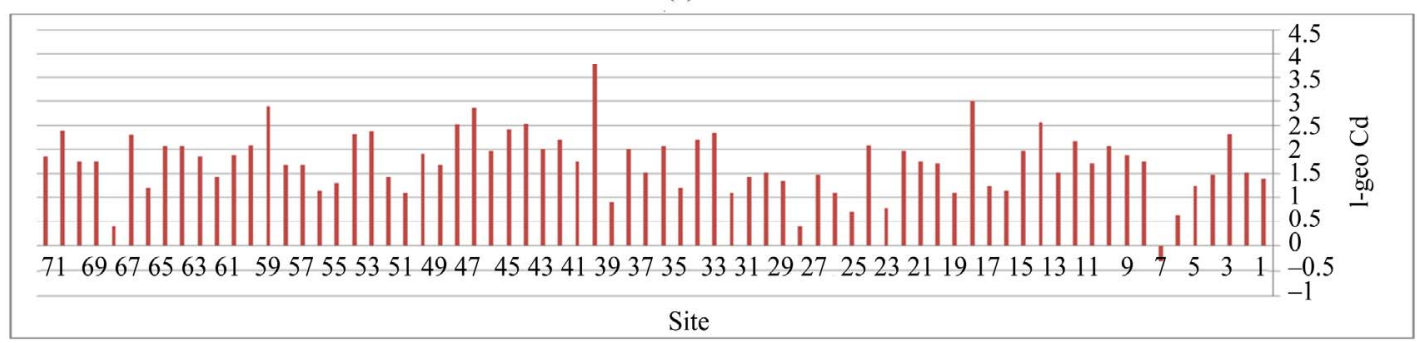

(f) 


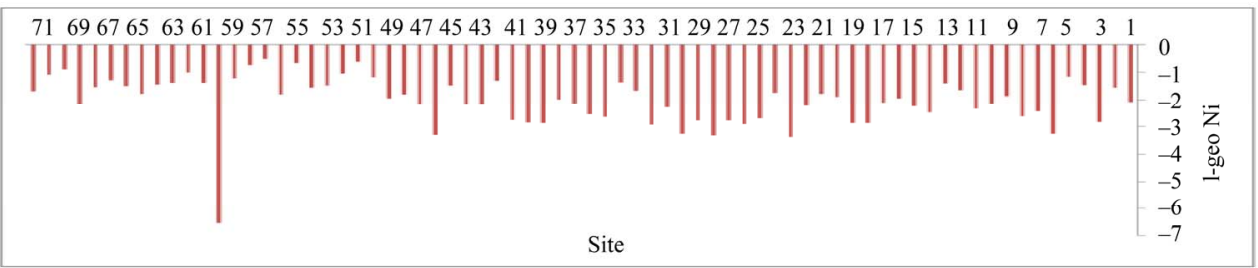

(g)

Figure 4. Index of Geo-accumulation for heavy metals Pb (a), Co (b), Cu(c), Fe (d), Zn (e), Cd (f) and Ni (g) in the study area.

28.11 and $18.53 \mathrm{mg} \cdot \mathrm{kg}^{-1}$ and the WHO standards for these metals are 68 and $19 \mathrm{mg} \cdot \mathrm{kg}^{-1}$ respectively.

The percentage of bioavilable metals to the total concentration of them for each studied metal are $\mathrm{Fe} 0.01 \%$, Cd $10.06 \%$, Co $1.72 \%$, Ni $2.04 \%$, Cu $2.83 \%$, Zn, $0.66 \%$ and $\mathrm{Pb} 8.04 \%$.

\section{REFERENCES}

[1] L. M. Gaetke and K. Chow, "Copper Toxicity, Oxidative Stress, and Antioxidant Nutrients," Toxicology, Vol. 189, No. 2, 2003, pp. 147-163. doi:10.1016/S0300-483X(03)00159-8

[2] S. Juvanovic, F. Carrot, N. Deschamps and P. Vukotic, "A Study of the Air Pollution in the Surroundings of an Aluminum Smelter Using Epiphytic and Lithophytic Lichens," Journal of Trace Microprobe Techniques, Vol. 13, 1995, pp. 463-471.

[3] P. W. Abrahams, "Soils: Their Implications to Human Health," The Science of the Total Environment, Vol. 291, No. 1-3, 2002, pp. 1-32. doi:10.1016/S0048-9697(01)01102-0

[4] R. Unterbrunner, M. Puschenreiter, P. Sommer, G. Wieshammer and P. Tlustos, "Heavy Metal Accumulation in Trees Growing on Contaminated Sites in Central Europe," Environmental Pollution, Vol. 148, No. 1, 2007, pp. 107-114. doi:10.1016/j.envpol.2006.10.035

[5] H. W. Mielke, C. R. Gonzales and M. K. Smith Mielke, "The Urban Environment and Children's Health: Soils as an Integrator of Lead, Zinc and Cadmium in New Orleans, Louisiana, USA," Environmental Research, Vol. 81, No. 2, 1999, pp. 117-129. doi:10.1006/enrs.1999.3966

[6] D. Baize and T. Sterckeman, "Of the Necessity of Knowledge of the Natural Pedo-Geochemical Background Content in the Evaluation of the Contamination of Soils by Trace Elements," Science of the Total Environment, Vol. 264, No. 1-2, 2001, pp. 127-139. doi:10.1016/S0048-9697(00)00615-X

[7] H. Xue, P. H. Nhat, R. Gachter and P. S. Hooda, "The Transport of $\mathrm{Cu}$ and $\mathrm{Zn}$ from Agricultural Soils to Surface Water in a Small Catchment," Advances in Environmental Research, Vol. 8, No. 1, 2003, pp. 69-76. doi:10.1016/S1093-0191(02)00136-3

[8] F. Pinamonti, G. Stringari, F. Gasperi and G. Zorzi, "The Use of Compost: Its Effects on Heavy Metal Levels in Soil and Plants," Resources, Conservation and Recycling, Vol. 21, No. 2, 1997, pp. 129-143.

\section{doi:10.1016/S0921-3449(97)00032-3}

[9] S. Cornu, N, Colin, J. P. Ambrosi, P. Whitehead, M. Neal, J. Sigolo and P. Vachier, "The Environmental Impact of Heavy Metals from Sewage Sludge in Ferrasols (Sao Paulo, Brazil)," Science of the Total Environment, Vol. 271, No. 1-3, 2001, pp. 27-48. doi:10.1016/S0048-9697(00)00814-7

[10] L. Hernandez, A. Probst, J. L. Probst and E. Ulrich, "Heavy Metal Distribution in Some French Forest Soils: Evidence for Atmospheric Contamination," Science of the Total Environment, Vol. 312, No. 1-3, 2003, pp. 195-219. doi:10.1016/S0048-9697(03)00223-7

[11] M. Abbasi, H. Mohammadi and M. Peyda, "Heavy Metal Contamination of Surface-Water and Groundwater of Vicinity Region of Zanjan Zinc and Lead Smelting Plant," Research Report, Zanjan Department of the Environment, 2000 .

[12] A. Chehregani, M Noori and H. Lari Yazdi, "Phytoremediation of Heavy-Metal-Polluted Soils: Screening for New Accumulator Plants in Angouran Mine (Iran) and Evaluation of Removal Ability," Ecotoxicology and Environmental Safety, Vol. 72, No. 5, 2009, pp. 1349-1353. doi:10.1016/j.ecoenv.2009.02.012

[13] F. A. Vega, E. F. Covelo, M. L. Andrade and P. Marcet, "Relationships between Heavy Metals Content and Soil Properties in Mine Soils," Analytica Chimica Acta, Vol. 524, No. 1-2, 2004, pp. 141-150. doi:10.1016/j.aca.2004.06.073

[14] J. Li, Z. M. Xie, Y. G. Zhu and R. Naidu, "Risk Assessment of Heavy Metal Contaminated Soil in the Vicinity of a Lead/Zinc Mine," Journal of Environmental Sciences, Vol. 6, 2005, pp. 881-885.

[15] H. Mohammadi and A. Eslami, "Quantity and Quality of Special Wastes in Zanjan Province," Research Report, Zanjan Department of the Environment, 2007.

[16] M. G. Whitten and G. S. P. Ritchie, "Calcium Chloride Extractable Cadmium as an Estimate of Cadmium Uptake by Subterranean Clover," Australian Journal of Soil Research, Vol. 29, No. 2, 1991, pp. 215-221. doi:10.1071/SR9910215

[17] ISO 11466, "Soil Quality-Extraction of Trace Elements Soluble in Aqua Regia," International Standard, 1995, pp. 1-6.

[18] A. Kelepertsis, et al., "The Environmental Geochemistry of Soils and Waters of Susaki Area, Korinthos, Greece," Environmental Geochemistry and Health, Vol. 23, No. 2, 2001, pp. 117-135. doi:10.1023/A:1010904508981 
[19] W. L. Lindsay and W. A. Norvell, "Development of a DTPA Soil Test for Zinc, Iron, Manganese, and Copper," Soil Science Society of America Journal, Vol. 42, No. 3, 1978, pp. 421-428.

doi:10.2136/sssaj1978.03615995004200030009x

[20] H. H. Huu, S. Rudy and A. Van Damme, "Distribution and Contamination Status of Heavy Metals in Estuarine Sediments near Cau Ong Harbor, Ha Long Bay, Vietnam," Geology, 2010.

[21] L. L. Mediolla, M. C. D, Domingues and M. R. G. Sandoval, "Environmental Assessment of an Active Tailings Pile in the State of Mexico (Central Mexico)," Re- search Journal of Environmental Sciences, Vol. 2, No. 3, 2008, pp. 197-208.

[22] G. M. S. Abrahim and P. J. Parker, "Assessment of Heavy Metal Enrichment Factors and the Degree of Contamination in Marine Sediment from Tamaki Estuary, Auckland, New Zealand," Environmental Monitoring and Assessment, Vol. 136, No. 1-3, 2008, pp. 227-238. doi:10.1007/s10661-007-9678-2

[23] R. A. Sutherland, "Bed Sediment-Associated Trace Metals in an Urban Stream, Oahu, Hawaii," Environmental Geology, Vol. 39, No. 6, 2000, pp. 611-637. doi:10.1007/s002540050473 